\title{
Library Provision for Undergraduates
}

I N September 1964 a deputation from the Association of Research Libraries met at Hull, England, with that country's Standing Conference of National and University Libraries to discuss common problems. Among other matters, the con- ferees directed their attention to library service to undergraduates, and-to evoke such discussion-the following two papers were read expressing the bases for English and American approaches to the problem.

B. S. PAGE

\section{In England}

"Library provision for undergraduates" I shall take to mean, first, book buying in relation to undergraduates, and secondly, administrative arrangements for the undergraduate in the library. I ought perhaps to state that the British point of view which I am about to present would appear slightly to the left of center if orthodoxy were measured, as it could very reasonably be measured, by the recent SCONUL submission to the University Grants Committee, Committee on Libraries-a document which I have naturally kept in mind as a standard and to which I shall appeal from time to time: ${ }^{1}$ the divergence, in so far as it is significant, doubtless owes something to the fact that I am at present occupied with planning a separate undergraduate library building for the University of Leeds-a building which will, to the best of my knowledge, be the first of its kind to be opened in this country since 1939.

The year 1939 is a good year in which to begin. In or about that year the following sentence was written by a distinguished British university librarian: "It

Mr. Page is Librarian of the Brotherton Library, University of Leeds. may be safely asserted that it is the aim of most university librarians to devote the minimum of expenditure to purchases which are only of interest to undergraduates in preparing for examinations, and to apply the great bulk of available funds to the acquisition of books and periodicals of a kind which assist research in as many fields as possible." The case would be stated rather differently now-less bluntly but still, I think, with a recognizable undertone of impatience; thus, the SCONUL document says: "This Conference would wish to stress the fact that every extra copy of a students' textbook acquired by the library means one less additional work purchased by the library." The competing claims of research needs and undergraduate study needs are indeed acutely felt in our university libraries partly because library budgets are still grossly inadequate and partly

\footnotetext{
1 In 1963 the University Grants Committee appointed a committee "to consider the most effective and economical arrangements for meeting the needs of the universities and the colleges of Advanced Technology and Central Institutions for books and periodicals. . . ." SCONUL in common with other professional bodies received from this committee a questionnaire covering most aspects of university librarianship, and its detailed reply to this questionnaire is the document referred to. This document is unpublished, but the brief quotations (which are included here by permission) are self-explanatory.
} 
because the British student has traditionally been expected to equip himself with the books essential for his course of study. In the last quarter of a century the student population has grown enormously (almost fourfold in my own university), the student himself is more insistent on his claims, and the appeal of self-help is noticeably less prominent in society at large. Whatever we may think of these tendencies, it seems hardly likely that we can influence them, and most university librarians would now accordingly take the view that they were called upon to duplicate-by which of course I mean "obtain multiple copies of"-a considerable number of students' textbooks and recommended books of one kind or another. They would, however, still wish to assume that there was a nucleus of essential books which the student bought for himself.

Most students do in fact buy at least a modest number of books-this has been shown by several recent investigationsand those students who are supported at the university by a state or local authority grant receive as part of this grant a sum of $£ 30$ a year for books, instruments, and materials, though nothing at all is done officially to ensure that the sum is used for the purpose intended. The SCONUL document says that "in some university libraries an attempt is made to encourage students to buy their textbooks by providing only reference copies of the books which students should buy for themselves." The difficulty in applying such an arrangement is to know precisely what are the books which students should buy for themselves; and therefore what is urgently needed is that members of the teaching staff should be persuaded always to indicate clearly both to their students and to the library which items on their reading lists they consider that the student should own and which he should obtain from the library. More interest in and more planning of students' reading by members of the teach- ing staff, and earlier and more continuous cooperation between them and the library would obviate much wastage of money and effort; the library would know in general where and when the demand would be greatest, and in a particular case could decide whether to acquire additional copies or temporarily restrict the circulation of existing copies. Admittedly the library may itself be at fault in not doing more to organize this cooperation. In the meantime some university libraries are reducing the tension of which I spoke earlier-the tension between research needs and study needs -by having separate funds for the duplication of students' books and also by harnessing the departmental library in the cause of providing more copies for an ever-increasing student body.

I now turn to my other main topic-the undergraduate in the library. It is a part of an undergraduate's education to find his way about a large collection of books: few university librarians would, I imagine, dissent in principle from this statement. Is the inference then that the undergraduate has only to be let loose in a large library to find his reward unaided? Quite frankly, I used to think that it was. I now see two difficulties: first, a university library is normally designed for research as well as for undergraduate study, and a time comes when the number of undergraduate readers is so large as seriously to impede the use of the main collections and main services by the research scholar. The undergraduate takes over the reading room, and if he is allowed, takes over the stack: he appropriates (not unreasonably from his point of view) any accommodation within sight. The Yale University librarian's report for 1959 says"We are continuing to look for, and adopt, measures which will care for both the undergraduate's need for a quiet place to study and the research scholar's need for ready access to our books and manuscripts and a quiet and orderly 
place in which to use them." My second difficulty is this: some students have the sort of intellectual curiosity which will enable them or rather compel them to make themselves at home in a large collection of books (these people of course are nature's librarians or researchers or both): but do most students really react in this way to a library of (to take a relatively low figure) half a million volumes? Do they not need a point d'appui, and do they not need also somebody strategically placed to give them guidance and stimulus?

If these two difficulties are genuine, there seems to be an undeniable case for having in a library of sufficient size with a student clientèle of sufficient size a separate division for undergraduates. (Mr. Bowyer in his admirable article in the Journal of Documentation ${ }^{2}$ says "a separate service," but I think that up to this point at least we should be in general agreement.) Separation does not of course mean segregation, and there is no thought of confining the undergraduate to a part of the library. On the other hand, as I have already intimated, one of the principal duties of the special staff of the undergraduate division would be to refer the undergraduate to the main collections. The SCONUL document warns of the danger that in "small undergraduate collections" the students will not venture outside their limits. But the less good student, whatever the library organization, will hardly venture even outside the limits of his prescribed reading unless he is actively encouraged to do so, and is he more likely to be encouraged in a functionally undifferentiated library or in one which provides a special service for his needs? The best student may be hampered by having to look for his material in two places, but no library can be so organized as to avoid this necessity altogether

2 T. H. Bowyer, "Considerations on Book Provision for Undergraduates in British University Libraries," Journal of Documentation, XIX (1963), 151-67. (even if it were desirable that it should). As to the size of the undergraduate collection, opinions differ. It has been said that a smaller collection, by showing its limitations, is better calculated to send the student elsewhere. It has also been said that a standard collection applicable to all libraries could be worked out by analyzing the demands of students in a particular library (this of course has a beguiling suggestion of economy, but suggestions of economy are in this context to be regarded with suspicion). My own belief is that standardization is not advisable (each library should build up its stock to meet its own conditions), that too small a collection looks dry and unappetizing and that there should be elbow room for browsing; if pressed to be more explicit, I should postulate that the size of the undergraduate collection should be adequate to give the undergraduate qua student an intelligible and attractive conspectus of the literature of each subject covered by the curriculum. I say "the undergraduate qua student" because of course the undergraduate is or ought to be for part of his time an apprentice in research and for this purpose will clearly need to make use of the main collections.

Lastly-what is perhaps the most controversial issue-is a separate building desirable? I should doubt whether "desirable" is the right word. If the undergraduate division could be suitably planned in the main university library building, this might well be ideal. Separate buildings have usually, perhaps always, been the result of a space problem in the main library. Yet it would seem possible to make a very sizeable virtue out of this necessity. Clearly the undergraduate library must be near the main library and must communicate with it as directly and as comfortably as possible. Granted this, your separate building could have an appeal of its own: the undergraduate might come to have 
toward it "a proprietary feeling" (this is Mr. Wagman's ${ }^{3}$ phrase) and might enter it more readily and more hopefully than if he approached it through the doors of the main library. With more students coming to our universities every yearmany of them a different type of student not so much dedicated to the pursuit of knowledge in a specialized field as concerned with continuing their education for a further three years-the undergrad-

Mr. Frederick Wagman, Director of Libraries, University of Michigan, Ann Arbor. uate library could conceivably be a powerful instrument in adapting the traditional values of a university to the needs of a new society. That of course is a large question, and outside my scope. The success of the separate undergraduate library from the practical point of view would depend very largely on two things: it must be inviting and stimulating as a building, and it must have a special staff ready to interpret it to the undergraduate not as a substitute for the main library but as an extension of it designed for his special benefit.

\section{STEPHEN A. McCARTHY}

\section{In the United States}

Prior to -World War II the common pattern of library organization and service in most American universities provided a central, general library which served faculty members, graduate students, and undergraduates. In most institutions there was also a system of departmental and college or school libraries which varied greatly in size and extent from institution to institution. Within the central library most of the services were common services; that is, they were intended to serve any member of the community who might have occasion to use them. In addition to the common core of services, there were certain services, such as interlibrary loan and rare books and manuscripts, which were primarily intended for and used by graduate students and faculty members; and there were other services, notably the reserve service, of which the heaviest use was made by undergraduates. In some relatively few institutions there

Dr. McCarthy is Director of Libraries at Cornell University. were rather more specialized provisions for undergraduates. These might take the form of special reading rooms either within the central building or elsewhere which undertook to concentrate for convenient use by undergraduates those materials which were most frequently used. In some institutions these were perhaps not much more than a special reserve collection, but there were instances as at Columbia and Chicago, where the college library included a small reference collection and supplementary and background reading material. Although there were these relatively few instances of special provision for undergraduates, it was generally true that the undergraduate found his library collection and services in the central library and as a part of the principal services of that library.

A major change in library service to undergraduates occurred with the opening of the Lamont library at Harvard in January 1949. The construction of a separate building designed to meet the particular needs of undergraduates and 
housing a collection chosen with the particular needs of undergraduates as the principal criterion of selection constituted a new and more positive attempt to provide high quality library service to undergraduates. Important as the Lamont library was in improving library service to undergraduates at Harvard, it seems probable that it may prove to have been even more important because of the new pattern of central library service which it established. In the years since 1949 , in a number of universities, the provision of a separate building, either through new construction or through remodeling, to serve as the undergraduate or college library has occurred. Plans announced or under discussion in still other institutions indicate that the next ten years will see the creation of additional undergraduate or college libraries. Thus in a period of roughly twenty-five years, the single central library will have been replaced in a group of American universities by a twobuilding central library, one of which will be especially devoted to service to undergraduates.

It should be immediately noted that although the separate undergraduate or college library has been adopted as the pattern of library service in a group of institutions, it has either not been considered or it has been rejected by others which provide central library service to the university community in a single building.

The separate undergraduate library has been regarded as a means of improving library service to undergraduates by giving them their own special facilities, a book and periodical collection chosen to meet their needs and a staff interested in providing library service to young college students. At the same time, the general or research library has been enabled to direct its attention and services primarily to the needs of graduate students and faculty and thus, it is assumed, has been able to provide improved service to these elements in the university community. Since both libraries are open to all students and faculty who wish or need to use them, no barrier is created by the division. Instead, it is hoped that use is facilitated by the nature of the collections and services and that easy transitions from one library to the other can be made as need arises.

Undergraduate libraries commonly are open-shelf libraries, with a series of reading rooms, group study rooms, alcoves and carrels, and facilities for typing, the use of microforms, and audiovisual materials. The organization tends to follow the traditional lines of circulation, reference, and reserve with modest provisions for periodicals and documents. In such buildings relatively little staff work space is required as acquisition and processing are normally carried on as part of the central operation.

In stocking the Lamont library, Harvard used a combination of library staff and faculty to select the volumes which comprised the basic collection. The published catalog of this collection has served as a guide in the formation of subsequent undergraduate collections with varying degrees of reliance. The shelflist of the undergraduate library at the University of Michigan has also been used as a guide. In most institutions that have formed undergraduate collections the effort has been made to enlist the assistance of the faculty in choosing the titles to be included.

The size of the collections in the undergraduate libraries has ranged from twenty to twenty-five thousand titles up to forty thousand and from thirty-five to fifty thousand volumes. The expressed intention has been that these collections would not exceed one hundred thousand volumes or one hundred twenty-five thousand volumes. When this size is reached, it is planned that the collections will be weeded and thus kept at an approximately stable figure. 
Up to this point it has not been noted that in each institution that has provided an undergraduate library there was serious need of additional library space. The undergraduate library has provided some of the needed space. The plan once adopted can be rationalized as a good, or a superior, means of rendering library service to undergraduates. It can be that. Approached in another way it can be argued that when book collections and the number of readers to be served become very large, it is desirable to break up the collections and the readers into smaller, more manageable units. The undergraduate library is one plausible way of making such a division. It is also apparent that for a given institution this device may provide an economical solution to a difficult capital funding problem. Regardless of the rationalization or explanation one may prefer to use, it seems likely that as enrollments continue to increase and as book collections continue to grow the separate undergraduate library will provide an attractive and useful form of decentralization of the central library service for many large institutions.

It should be clear, however, that not all American university librarians regard the undergraduate library as the best means of serving undergraduates. Direct exposure to a large book collection, not one especially selected for him, is considered a valuable educational experience for the undergraduate. This is best provided in a single central library in which undergraduates have access to the stacks.

Another approach, perhaps a new type, is exemplified in the new Notre Dame library in which the first two floors constitute the college library and the research library is housed in a tower stack. The college library is conceived as serving a broader function than service to undergraduates-it serves the entire university community with an openshelf collection of the more commonly used books. The user goes to the research stack when he requires less frequently used material.

The experience of American university libraries in their growth and expansion indicates that there are various ways of providing library service to undergraduates and that in the varying circumstances in which institutions find themselves it is important for each institution to analyze its own needs and adopt or devise the best solution it can support.

\section{ACRL Professional Booth At Conference}

IF yOU WANT INFORMATION about ACRL activities come to booth 1380 in the professional exhibit area at the Detroit Conference. Arrangements for servicing the booth are being made by the ACRL Committee on Local Arrangements under the chairmanship of Robert T. Grazier, Wayne State University. Other members of the committee include Carl Orgren, University of Detroit; Mary Ruskin, Oakland University, Rochester; Norman Tanis, Henry Ford Community College, Dearborn; and Harold Young, University of Michigan Dearborn Center. 